\title{
PSYCHE.
}

\section{THE HABITS OF THE ACULEATE HYMENOPTERA.-II.}

\author{
BY WILliaM H. ASHMEAD, WASHiNGTON, D. C.
}

Mr. E. Baynes Reed, in "Notes on Megachile brevis Say" (Can. ent. v. 3, 1871, p. 210) has figured this species and records the following respecting it.

While inspecting during the past summer, the fruit orchard of a friend residing in this neighborhood, my attention was attracted by the peculiar appearance of the leaves of a young plum tree. At the first glance, I thought it might be affected by Aphides, but, on closer examination, I found unmistakable evidence of the work of a leaf-cutting bee, in the circular holes in many of the leaves, and on opening one of the coils of leaves, of which there were four or five, I discovered the curious chambers of the bee, each containing a half grown grub comfortably ensconced, with its modicum of food. I took some of the coils home, but only succeeded in rearing two perfect insects.

The genus Osmia, structurally, is closely allied to Megachile, but the species composing it construct nests entirely different. They have received the name of "mason-bees," from the way they construct small earthen cells under stones, in burrows excavated in decaying wood, rotten posts and twigs, in deserted snail-shells, in cynipidous galls, or elsewhere.

Very little seems to be known respecting the habits of the North American species, Dr. Packard, in his Guide, being apparently the only author who has written anything about them. From his observations and those published abroad, the species exhibit great diver- sity of habits and should be more carefully studied, as this diversity of habits will no doubt be found correlated with structural differences that will justify sub-generic divisions of this large genus.

The cells are constructed of sand, earth, or clay, agglutinated and mixed with pebbles or the raspings of wood, held together by a glutinous substance secreted by the female; internally the cells are always smooth, but externally they are rough in conformity with the material used in their construction. These cells vary in number in each nest, usually from to to 20 being found together. Each cell contains a deposit of honey-paste for the subsistance of the larva, only a single larva or egg being found in each cell. Curtis found the enormous number of 230 cells of the European Osmia parietina attached to the under side of a large flat stone. $\mathrm{Mr}$. L. O. Howard, in his article in the Standard Natural History, calls attention to a remarkable case of retarded development in this species observed by Mr. Frederick Smith. "From a quantity of cells collected in Scotland in r849, about one-third only had given forth the adult bees. Some of the remainder issued the following year, while about thirty-five remained in the larva state until May, 185I, when they transformed and issued a month later."

One of our largest species, Osmia lignivora Pack., according to Dr. Packard, 
industriously tunnels out an elaborate burrow in maple several inches from the bark, wherein it forms its cells.

The tunnel was over three inches long and about three-tenths of an inch wide. It contracted a little in width between the cells, showing that the bee worked intelligently, and wasted no more of her energies than was absolutely necessary. The burrow contained five cells each half an inch long, being rather short and broad, with the hinder end rounded while the opposite and next to the one adjoining, is cut off squarely. The cell is somewhat jug-shaped, owing to a slight constriction just behind the mouth. The material of which the cell is composed is stout, silken, parchment-like, and very smooth within. The interstices between the cells are filled with rather coarse chippings made by the bee.

The bee cut its way out of the cells in March, and lived for a month afterwards on a diet of honey and water. It eagerly lapped up the drops of water supplied by its keeper, to whom it soon grew accustomed, and whom it seemed to recognize."

Osmia lignaria and O. pacifica Say, on the contrary, build their cells under stones, while $O$. simillima Smith, one of the smallest of our species, constructs its cells in the deserted oak-galls made by Amphibolips confluens Harris, thus agreeing with Osmia gallarum of Europe. I have also observed another species in a deserted oak-gall in Florida.

Species in the genus Anthidium, according to Westwood, "frequent various woolly-leaved flowers, stripping off the down with their toothed jaws for the purpose of forming their nests "

The Anthidii, as with certain Odyneri, although said to nidificate usually in holes in trees, will sometimes choose odd situations for their nests, the British species Anthidium manicatum having been twice observed to nidificate in the key-hole of a garden gate. Prof. Westwood thus describes one found in a similar position.

There were twelve or fifteen cells or cases consisting externally of a loose covering of white down within which was another covering more compact and smooth on the inside and within this was contained an oval cell, of a strong coriaceous texture, and of a chestnut color. This latter 1 consider to be the cocoon formed by the larva itself, because some of my woolly cases contained a mass of matter apparentiy consisting of dried pollen-paste and the egg deposited with it which had probably on some account proved abortive; and in these there was no oval chestnutcolored cocoon. It was in February that this nest was discovered, at which period some of the cells were empty, the inhabitants having forced off a circular cap from the top of the cocoon and escaped; others, however, contained full-sized grubs.

No observation seems to have even been published on any of our numerous species, although many of the species are so plentiful.

The genera Coelioxys Latr. and Stelis Panzer are parasitic bees, both having been bred in Europe; the former from the cells of Megachile, Anthophora and Anthidium, the latter from Osmia. No observations on any of the American species have ever been recorded.

Although the parasitic habits of Stelis was so long known it was not until last year that the true inward history was given in the publication of Mr. C. Veshoeff's observations on 
Stelis minuta Nyl. (Zool. anzeiger, vol. $\mathrm{xv}, \mathrm{I} 892$, pp. $4^{\mathrm{I}-43)}$.

This species was found to be parasitic in the nests of Osmia lẹcomelaena Kirby which constructs its cells in hollow twigs. Dr. Riley's summary of this species is as follows:-

At the bottom of the cell the female Osmia first puts a layer of pollen which is to serve as food for the nearly full grown larva. Above this pollen, the bee commences to store the cell with prepared bee-bread. At this moment the female Stelis watches her opportunity to lay an egg in the Osmia cell, the egg thus being always near the bottom (posterior end) of the food mass. Unaware of the presence of the parasite egg, the Osmia female continues her work, and, after nearly filling the cell, deposits her own egg on the top (anterior end) of the food mass. The cell is then closed with a layer of macerated particles of plants and a second cell prepared above the first. The Stelis larva hatches but little earlier than that of the Osmia, and both larva feed on the foodmass, the parasite larva at the bottom, the host larva at the top. The latter remains stationary at the top and grows very slowly; the parasite larva grows more rapidly, and gradually works its way upward through the food-mass, thus gradually approaching the Osmia larva. The crisis finally comes; the Stelis larva encounters the Osmia larva-a short but deadly combat ensues-the Osmia larva is easily overpowered and killed by the much larger and stronger parasite, and its body is devoured by the latter within one or two days.

The genus Epeolus is stated by our American authorities to be parasitic in the cells of Colletes, evidently based upon an observation of an English authority, Shuckard, who claims to have bred Epeolus variegatus from the cells of one of these bees.
This statement must, however, be erroneous, as it does not agree with observations of mine made on a common American species. It was evidently based upon insufficient data, just as was found to be the case repecting St. Fargeau's statement about Sphecodes being parasitic in the cells of Halictus.

The past summer, while in Mississippi, I was fortunate enough to stumble upon several specimens of Epeolus donatus Smith making their burrows, and I am thus enabled to assert that this species is not parasitic but builds cells and deposits honeypaste for its offspring, just as many other solitary bees. My observations throw grave doubts upon the reliability of Shuckard's statement and lead me to believe that he had cells of both Epeolus and Colletes mixed together in his breeding jars, when his specimens were reared.

On the plantation where I was staying, near Utica, Miss., Epeolus donatus was observed making its burrow in hard clay, beneath a cotton-gin shed, into which I had run to escape a passing rain storm which came on suddenly, while I was investigating cotton-insects in a cotton-field near by.

My attention was first attracted by the buzzing of the bees; for, as they returned from the field to enter their burrows, before alighting they invariably made several circles above the mouth of their burrow, all the time making a very loud humming or buzzing noise, very noticeable and which ceases only as they reach the ground. 
I thus easily discovered several burrows and afterwards saw females in the act of digging them.

All except three or four had the peculiar tubular entrance formed of cemented clay at their mouth, similar to those made by Anthophora and other solitary bees. Burrows that had not the tubular entrance at their mouth, evidently had it originally, but it had become destroyed by persons or cattle walking over the ground where the burrows occurred.

The clay was very hard and dry, and the burrows extended in it obliquely downward to the depth of two or three inches and then became horizontal, terminating after reaching a depth of eight or ten inches. At the bottom the female builds her cell, composed of cemented clay, $15 \mathrm{~mm}$. long by $10 \mathrm{~mm}$. in diameter at widest part, the cell being slightly constricted towards the top, where its diameter is only $8 \mathrm{~mm}$.; interiorly it is perfectly smooth and glistening from some thin secretion that covers its surface, while exteriorly it is rough from the small particles of clay of which it is composed. Some of the cells dug up were only partially finished; others were completely finished, either empty or contained the egg or the larva.

The egg was always enclosed in a ball of honey-paste that was perfectly white and consisted of numerous white granules mixed with honey. Only one egg was found in each cell. The egg is much elongated and slightly thicker toward one end, perfectly white, with its surface feebly shagreened. One taken from its cell August 15, measured $4 \mathrm{~mm}$. long, hy $0.8 \mathrm{~mm}$. in diameter, at its thickest part.

A larva, taken August 16, doubled up in its cell, measured $\mathrm{r} 2 \mathrm{~mm}$. long, while the broadest abdominal segment measured only $5 \mathrm{~mm}$. It tapered very much toward the head, was of a white color, with the derma finely, irregularly transversely shagreened, the segments being well defined; the head was small, rounded, measuring transversely I.5 $\mathrm{mm}$.; the eyes were not apparent except by a slight elevation, which was scarcely separable from the cranium; the mandibles were well defined, black or piceous at the tips, the tips being truncate and roundedly emarginate but not sufficiently emarginate to form distinct teeth; the clypeus was trapezoidal, the anterior edge with a medial emargination; while the other parts of the mouth were not developed, appearing as three lobes, a lobe beneath each mandible, with the third placed beneath and more or less covering the other two.

Although still incomplete, these observations prove this bee is not parasitic and will serve to stimulate further study on the habits of our species.

It may be well to record here that while studying this species, I observed a Mutillid moving cautiously into one of the burrows, which on capturing proved to be Sphaerophthalma simillima Smith. It is probably parasitic on this bee.

The species belonging to the genera Nomada Fabr. and Melecta Latr. are stated to be parasitic on different soli- 
tary bees, although additional evidence is needed to establish the sort of parasitism it is.

Dr. Packard has reared Nomada imbricata Smith and $N$. vincta Say (= pulchella Sm.) from the nests of Andrena vicina Smith; and the former also from the cells of Halictus parallelus Say and found:

Both full-grown larvae and pupae of different ages, up to the adult Nomada, ready to take leave of its host. It seems, therefore, that the newly hatched young of Nomada must feed on the pollen mass destined for the Andrena. But there seems to be enough for both genera to feed upon, as the young of both host and parasite were found living harmoniously together, and the host and their parasites are disclosed both at the same time.

Is it not just possible that this sociability of the two larvae is fictitious and lasts only just so long as the food supply is sufficient for both? When the food supply gives out, will they not also attack each other just as in the case of Stelis?

It seems to me that here we have an admirable illustration of the origin of parasitism. We have (I) commensalism, (2) parasitism, induced by hunger, and (3) genuine parasitism, which is induced or acquired by the two former. conditions, until finally it becomes permanently acquired through heredity. The same thing is strikingly exhibited in the family Cynipidae where we find (I) gall-makers, (2) commensals or inquilines and (3) true parasites, again in the family Chalcididae, in the Eurytomides where we have (1) gall-makers or plantfeeders (Isosoma and allies), (2) commensals or inquilines (Eurytoma and allied genera) and (3) true parasites (Bruchophagus, Eurytoma, etc.). The same state of affairs occurs also in the fig-insects (Blastıphaginae), and in the gall-inhabiting Toryminae.

Family $I I$. Andrenidae. In habits and structure this family is in all respects very closely allied to the preceding. About 150 species, distributed in 14 genera, are already known from boreal North America.

All of the genera, except the genus Prosapis Fabr., which like Ceratina, in the preceding family, excavates the stems of brambles, etc., burrow galleries in the ground in which they place their cells. At one time two or three of the genera, Sphecodes, Augochlora and Prosapis, were considered to be parasitic or inquilinous in the cells of some of the others, but have since been shown to be honey-producers like the rest.

The nests of comparatively few of our genera have been studied in detail. Andrena vicina Smith, as observed by Mr. J. H. Emerton and others, excavates a perpendicular gallery in the ground to the depth of several inches or more, branching off from which it then excavates short oblique galleries in which the cells which are lined with a muscous-like secretion are placed.

The nests are built in the latter part of April and during May. The cells are then filled with a ball of pollen and 
honey, those nearest the surface being provisioned first, those at the bottom last. The period of development from egg to imago is about five weeks, so that imagos issue all through July and August.

The genera Cilissa Leach, Nomia Latr. and Halictus Latr. have similar habits.

The nests of Auglochlora pura, as recorded by Say (Bost. Journ., v. I, I 837, p. 397) were found in the soft, decomposing sap-wood of the oak and hickory, between the bark and the solid wood.

The cells are oval, horizontal, not symmetrically disposed though many are parallel. These cells are composed of particles of the decayed wood agglutinated together. Each cell contains one individual subsisting on a yellow-pollen. In the same assemblage are the young of all ages to the perfect insect.

The habits of none of our species of Prosapis and Colletes have been observed.

A Dipteron Miltogramma punctata has been reared from Colletes in Europe.

Family III. Crabronidae. This family is represented in our fauna by over one hundred species, unequally distributed in seven genera. The species, according to the "records," exhibit the greatest diversity in their habits. Westwood says, "Those whose economy has been clearly traced make their cells in wood, boring into palings, posts, willows, stumps, etc."
No observations have been made on our species belonging to the genus Oxybelus, but in Europe they are found to burrow in sand and to provision their nests with dipterous insects. Verhoeff states that the species in this genus do not paralyze their prey by stinging like most other fossorial wasps as they are unable to do so on account of the rigidity of the abdomen, but instead they crush the thorax with the mandibles just beneath the wings, the centre of the nervous ganglia. $\mathrm{He}$ found in one nest a dozen flies (Hydrotaea) and all had their thorax crushed and were dead. According to Fabre Oxybelus makes no use of its mandibles and legs in carrying its prey, but instead carries it home on its sting! The genus in Europe is parasitized by Miltogramma conica.

Shuckard tells us that Crabro cephalotes "employs its mandibles in forming a cylindrical cell in decaying trees passing the particles of wood beneath them and ejecting them behind by means of the spines on the posterior tibiae"; Latreille that Crabro cribarius provisions its nest with the larva of Tortrix chlorana, which feeds upon the oak. This last differs, however, from Shuckard's observations, who found this species, as well as $C$. patellatus and other species, storing their nests with Diptera. Crabro leucostoma was observed by Westwood making its burrow in rotten wood and provisioning with Anthomyia pluvialis; he also relates that a Crabronid nest given to him by Mr. Pickering, 
found in rotten wood was provisioned with blue-bottle flies and from which he reared Crabro vagus.

Our native species of Crabro are numerous but very little is recorded respecting their habits. Packard states that Crabro sex-maculatus Say, according to Dr. T. W. Harris' ms. notes, was seen June io by Mr. Leonard of Dublin, N. H., burrowing in decaying wood, while Crabro singularis Smith was discovered by Mr. C. A. Shurtleff boring in a post.

Mr. Wm. Couper, in an article entitled "Nest of Crabro sex-maculatus Say" published in Can. ent., i (I869), p. 77, figures and describes the nest of a bee that was identified for him by Dr. Packard as this species, but which clearly must be a mistake, due undoubtedly to $\mathrm{Mr}$. Couper sending the Doctor the wrong insect as the maker of the nest.

The nest was made in tops of raspberry canes, the pith having been extracted by the bee and the interior then utilized for the reception of the cells, which were filled (according to $\mathrm{Mr}$. Couper) with pollen. Mr. Couper found the eggs and the larvae in various stages of development, but tells us nothing about their further development, or whether he succeeded in rearing the imago.

Altogether the article is very unsatisfactory and I do not believe it to be, what it is represented, the nest of Crabro sex-maculatus Say, which is a fossorial wasp and not a bee.

Species in the genus Rhopalum
Kirby are said to bore into the stems of pithy plants and to prey upon spiders and Aphides.

The genus Trypoxylon, which probably represents a distinct family, has similar habits, although most of the species are "lazy fellows" seldom taking the trouble to build a nest for themselves, preferring to "crib" one from some other wasp, or then to utilize an old deserted cell or then any hole or crevice they can find, which is suitable for them to build their cells for their supplies. This peculiarity caused them at one time to be considered parasitic.

Walsh was the first to record the habits of Trypoxylon albitarse which usually selects the deserted cells of a mud-dauber (Pelopaeus) in which to nidificate, provisioning its cells with spiders. I can confirm this statement of Walsh's from personal observations as I have not only obtained them from the old cells of Pelopaeus but also from those of Chalybion caeruleum. I have also bred $T$. clavatum Say from the same mud-dauber's cell.

Trypoxylon carinifrons Fox, $T$. collinum Smith, and $T$. albopilosum Fox, on the contrary, carry off Aphides with which to provision their cells. The first, which is the smallest species, takes up its abode in the round holes made by Scolytids in pine-timber, into which I have seen them going carrying Chaitophorus salicicola Monell, obtained from a willow close by. This species is parasitized by an equally small Chrysid, Chrysis verticalis Pattn. The second I have seen carry. 
ing Chaitophorus lonicera Monell into a burrow made in hard or compacted sand, probably containing cells made by some other insect; while the third I have seen capturing and carrying off a maple aphis, Chaitophorus sp.

Family $I V$. Pemphredonidae. According to Mr. Fox's recent Synopsis, this family is represented in our fauna by 6 genera and 27 species.

Shuckard considered the genus Passaloecus to be parasitic in its habits, based upon a superficial observation on $P$. insignis, and this opinion seems to be supported by Kirchner, who records $P$. turionum Dahlb. as a parasite of Tortrix resinanae. Westwood, however, states that $P$. gracilis Curt. and $P$. corniger Shuck., as observed by $\mathrm{Mr}$. Kennedy, provide Aphides for the food of their progeny, carrying them in the mouth into cells placed in holes in posts.

This agrees with an observation of mine on a common American species, Passaloecus annulatus Say, several of which I have taken as they went in and came out of their burrows in the bark of an old pine tree, and from which I afterwards dug out their cells, which were made of clay. I believe, therefore, that Shuckard and Kirchner are wrong in calling these insects parasites. In fact, all the species in this family, except those belonging to the genus Diodontus, are typical wood-wasps, forming their nests or cells in rotten wood, decaying bark of trees or in hollow stems of plants, and provisioning the same with Aphides or other small insects.
Diodontus minutus Fabr. and $D$. tristis Dahlb., two European species, have been observed to burrow in sand; and this agrees with what I have observed of the American species Diodontus americanus Pack., two specimens of which I have captured while in the act of burrowing in hard clay, while other specimens were observed going in their burrows near by. An effort was made to investigate two or three of these burrows, but the holes were so exceedingly small as to baffle me in my efforts, filling up rapidly as I attempted to dig them out with my pocket knife and leaving no trace to follow. The burrows evidently extended to a considerable depth.

Westwood says Pemphredon lugubris Fabr. burrows in decayed wood and provisions its nest with Aphides. In Florida, I have observed Pemphredon angularis Fox carrying off pine Aphides but never succeeded in finding its nest.

Cemonus westmaeli Morowitz, is reported to form its nest in the stems of Rubus, Sambucus, the deserted oakgall Cynips kollari, or even in the empty cocoon of Lipara lucens.

Mr. Kennedy, according to Westwood, discovered that Stigmus troglodytes formed its cells in hollow straws of a thatch, which it filled with minute insects apparently the larvae of a Thrips, as many as fifty being found in one cell.

Stigmus argentifrons Ashm. Ms. provisions its cells with immature Aphides from the honey-suckle. 

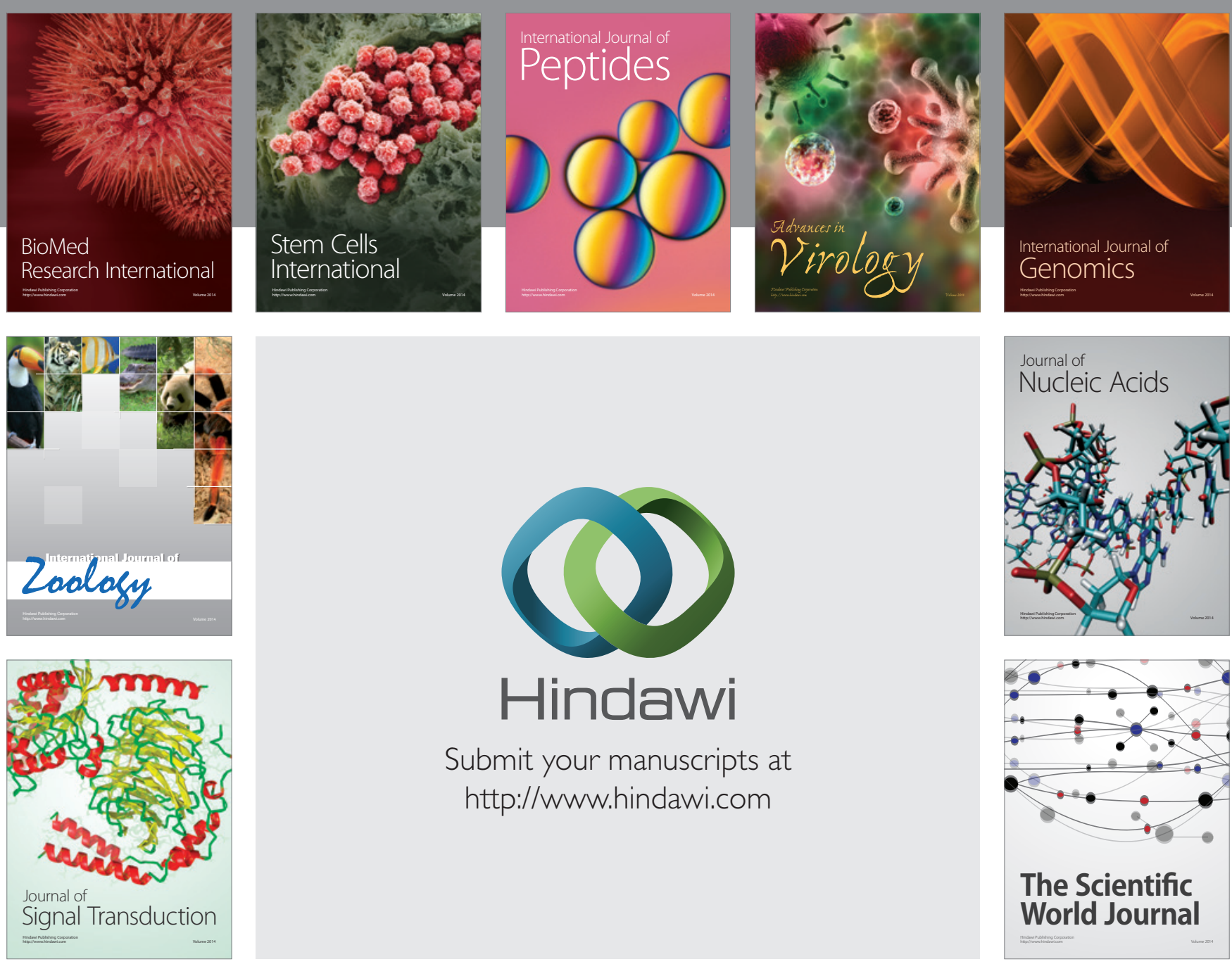

Submit your manuscripts at

http://www.hindawi.com
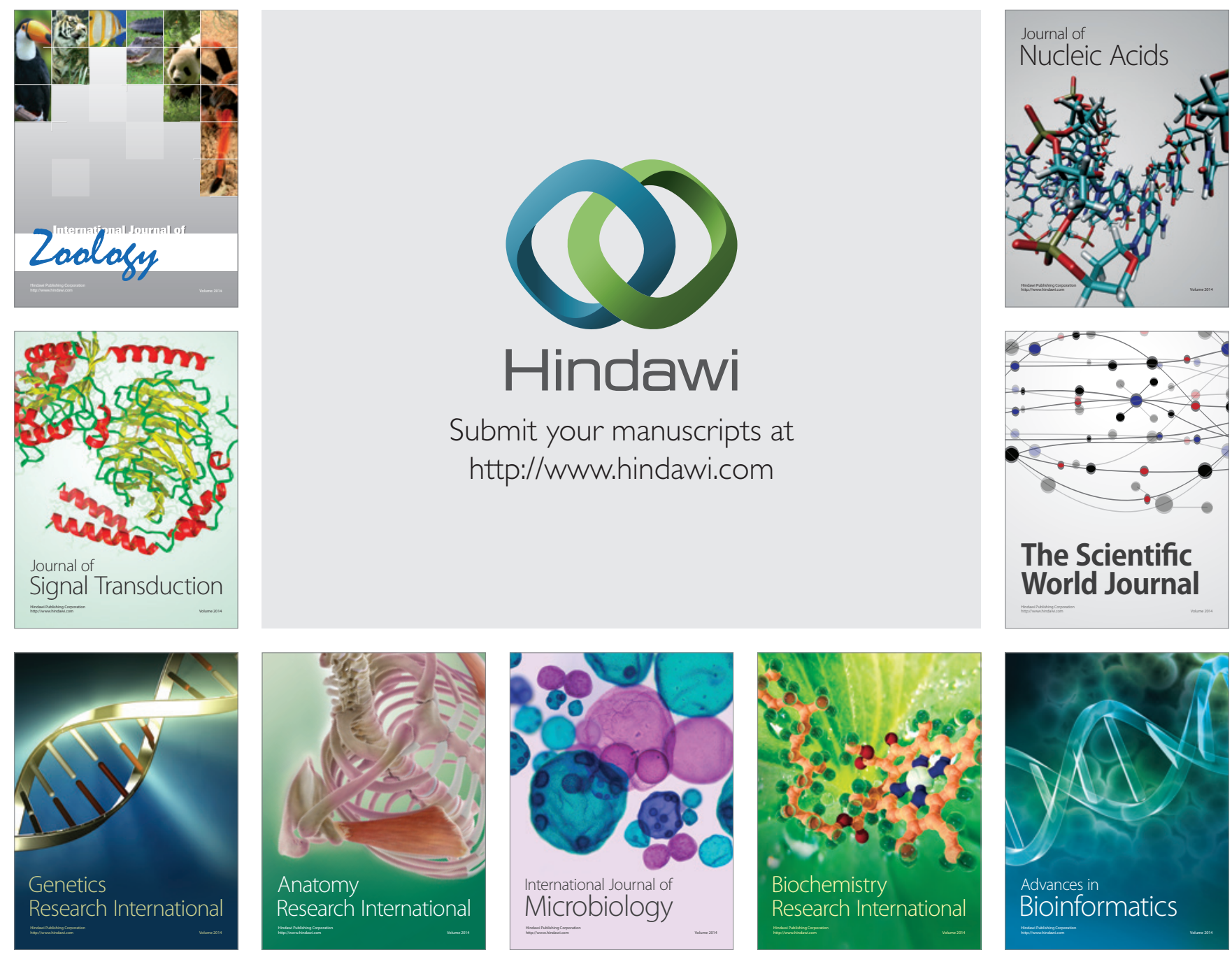

The Scientific World Journal
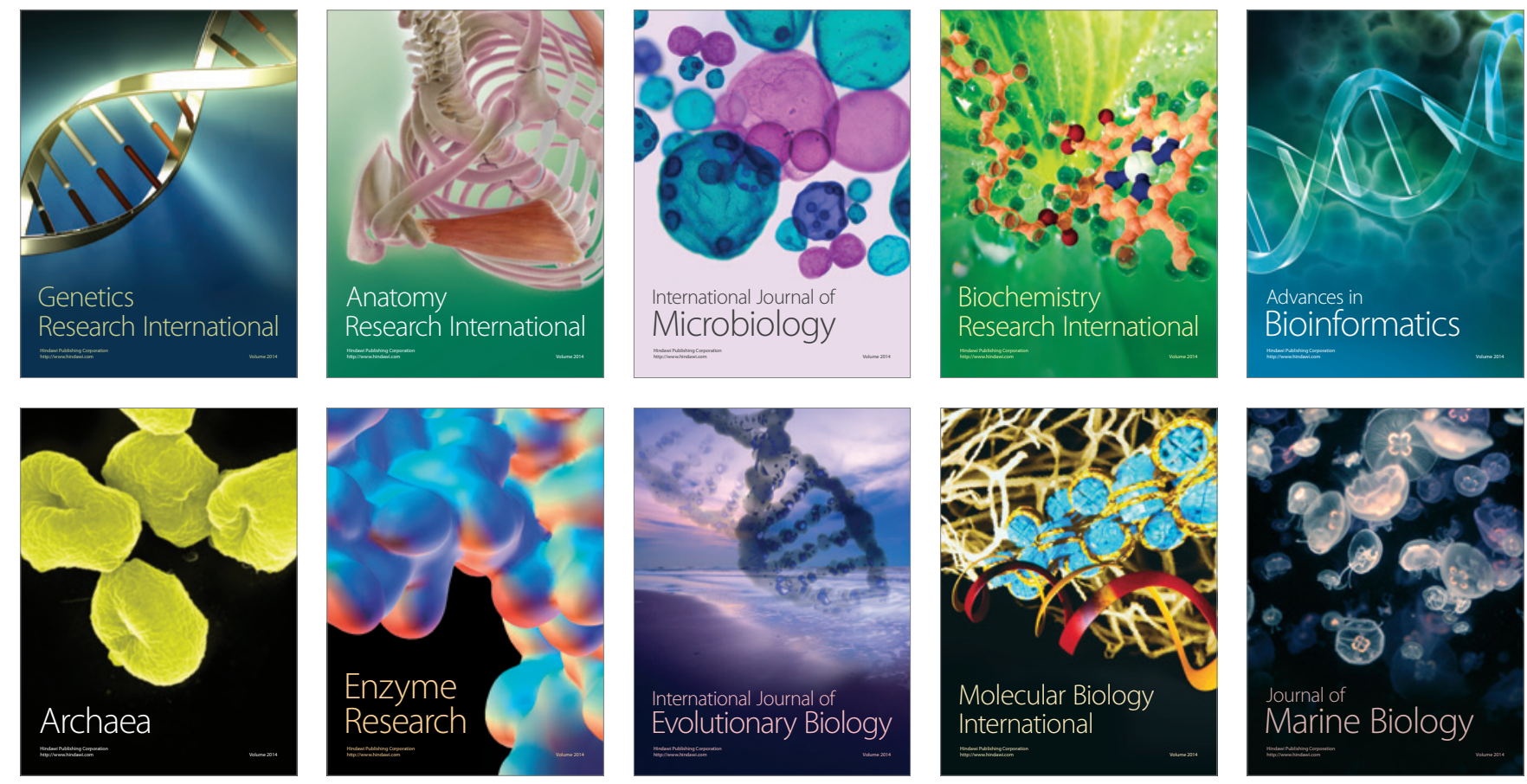